\title{
PENGEMBANGAN USAHA TERNAK LEBAH MADU HUTAN NAGARI SUNGAI BULUH NAGARI SUNGAI BULUH TIMUR KECAMATAN BATANG ANAI KABUPATEN PADANG PARIAMAN
}

\author{
Revita Yuni $^{1 *}$, Pebri Hastuti ${ }^{1}$, Roni Afriadi ${ }^{2}$, Putri Sari Silaban ${ }^{1}$ \\ ${ }^{1}$ Fakultas Ekonomi, Universitas Negeri Medan, Medan, Indonesia \\ ${ }^{2}$ Fakultas Ilmu Tarbiyah dan Keguruan, Universitas Islam Negeri Sumatera Utara, Medan, Indonesia \\ *Penulis Korespondensi: revitayuni25@gmail.com
}

\begin{abstract}
Abstrak
Salah satu peran swasta dalam implementasi Good Corporate Governance (GCG) terwujud melalui aktualisasi program Corporate Social Responsibility (CSR). PT. PERTAMINA (Persero) Terminal DPPU BIM Kataping Padang Pariaman sebagai salah satu unit bisnis PT. PERTAMINA (Persero) menyadari posisinya sebagai bagian dari masyarakat, oleh sebab itu turut berperan serta dalam pengembangan masyarakat di wilayah operasi perusahaannya sebagai wujud tanggungjawab sosialnya melalui program CSR. Program yang dimaksud difokuskan pada proses pemberdayaan masyarakat yang diklasifikasikan ke dalam aspek ekonomi, pendidikan, kesehatan, lingkungan, infrastruktur sarana dan prasarana dan social budaya secara berkelanjutan, guna memandirikan masyarakat dan menjawab kebutuhan kelompok rentannya. Harapan dalam setiap program memiliki tujuan akhir yang mampu menciptakan kesejahteraan bagi masyarakat. Pendekatan pelaksanaan CSR dilakukan melalui pemberdayaan dengan memposisikan penerima manfaat program harus difasilitasi dengan program yang berkelanjutan dengan mengakomodasi proses komunikasi secara internal maupun eksternal. Salah satu upaya pengendalian mutu pelaksanaan program CSR diperlukan monitoring dan evaluasi terhadap pelaksanaan program yang dilakukan PT. PERTAMINA (Persero) Terminal DPPU BIM Kataping Padang Pariaman, dengan melaksanakan kegiatan monitoring dan evaluasi dengan meninjau pelaksanaan program secara menyeluruh, baik dari aspek input, proses, output, outcome dan impact. Hasil evaluasi tersebut akan diposisikan sebagai acuan perbaikan program yang akan dilaksanakan pada periode selanjutnya.
\end{abstract}

Kata Kunci: Pemberdayaan Masyarakat, Inovasi Produk.

\begin{abstract}
One of the roles of the private sector in the implementation of Good Corporate Governance (GCG) is realized through the actualization of the Corporate Social Responsibility (CSR) program. PT. PERTAMINA (Persero) Terminal Kataping DPD BIM Padang Pariaman as one of the business units of PT. PERTAMINA (Persero) realizes its position as part of the community, therefore participating in community development in the company's operational area as a form of its social responsibility through CSR programs. The program in question is focused on the process of community empowerment which is classified into economic aspects, education, health, environment, infrastructure facilities and infrastructure and social culture in a sustainable manner, in order to empower the community and answer the needs of vulnerable groups. Hope in each program has the ultimate goal of being able to create prosperity for the community. The approach to implementing CSR is carried out through empowerment by positioning program beneficiaries to be facilitated with sustainable programs by accommodating communication processes internally and externally. One effort to control the quality of the implementation of the CSR program requires monitoring and evaluation of the implementation of the program carried out by PT. PERTAMINA (Persero) Terminal BIM Kataping DPPU Padang Pariaman, by carrying out monitoring and evaluation activities by reviewing the overall implementation of the program, both from input, process, output, outcome and impact. The results of the evaluation will be positioned as a reference for improving the program that will be implemented in the next period.
\end{abstract}

Keywords: Community Empowerment, Product Innovation.

\section{PENDAHULUAN}

Di Indonesia banyak jenis lebah madu yang merupakan suatu keuntungan guna peningkatan hasil hutan non kayu. Potensi yang besar ini harus didukung oleh pemanfaatan yang optimal dan lestari. Hal ini juga akan memberikan manfaat terhadap peningkatan ekspor 
madu Indonesia serta peningkatan kesejahteraan dan pendapatan masyarakat. Lebah madu memiliki banyak manfaat seperti hasil langsung berupa madu, pollen, royal jelly, propolis zat perekat dan sengatan lebah. Manfaat tidak langsung dari usaha budidaya lebah madu diantaranya berupa peningkatan gizi masyarakat, menciptakan lapangan pekerjaan serta membantu penyerbukan tanaman hutan dan tanaman pertanian sehingga kelestarian hutan di Indonesia dapat terjaga serta produksi pertanian meningkat. Berkurangnya hutan Indonesia berakibat semakin berkurangnya habitat lebah madu, dengan demikian akan semakin terjadi penurunan hasil madu. Dengan membudidayakan lebah madu dapat mengatasi kekurangan habitat lebah madu tersebut.

Lebah madu merupakan kelompok serangga yang berperan sebagai agen polinator tanaman berbunga, sehingga dapat meningkatkan produksi tanaman tersebut (Corlett, 2011). Lebah madu dan tanaman berbunga memiliki hubungan yang saling menguntungkan yaitu tanaman sebagai penyedia pakan lebah berupa nektar dan polen, sedangkan lebah madu melakukan proses polinasi tanaman tersebut. Lebah madu memperoleh pakan nektar dan polen dari bunga tanaman yang dikumpulkan secara kontinyu oleh lebah pekerja. Nektar merupakan cairan manis yang disekresikan oleh kelenjar nektaris tanaman yang dapat berkembang pada bagian bunga, daun dan batang. Nektar dan polen yang dikumpulkan oleh lebah sebagai sumber karbohidrat, protein, lemak, vitamin, mineral yang esensial dibutuhkan untuk pertumbuhan, perkembangan, memperbaiki jaringan dan menstimulasi perkembangan kelenjar hypopharyngeal (Abrol, 2011). Polen atau tepung sari merupakan produk yang dihasilkan oleh alat kelamin jantan tanaman yang berbentuk tepung dan merupakan bahan baku untuk memproduksi bee-pollen oleh lebah pekerja. Polen tersebut mengandung protein, vitamin dan mineral yang dbutuhkan oleh lebah madu dalam membangun koloni yang sehat (Sihombing, 2005; Abrol, 2011).

Program pemberdayaan masyarakat di Hutan Nagari Sungai Buluh diberikan kepada petani lebah madu dengan memberikan pelatihan pembudidayaan lebah madu serta pengadaan sarana pembudidayaan. Sumbangan peralatan meliputi bibit lebah, kotak lebah, alat pengasap, pengungkit sisiran, sikat sisiran lebah madu, pollen trap, frame atau bingkai yang dipergunakan lebah untuk bersarang, kotak sarang, alat pemisah madu, dan ekstraktor yang dipergunakan saat panen madu.

Berdasarkan hasil identifikasi dilapangan terungkap bahwa permasalahan yang dihadapi para petani pembudidaya lebah madu diantaranya kurangnya pakan lebah dalam jumlah memadai ekstraktor yang masih sederhana dan belum maksimal, kurangnya pengetahuan petani lebah, kualitas produk dan kemasan yang kurang baik serta pemasaran produk masih dilakukan sendiri. Tujuan penulisan ini berfokus kepada penjabaran pelaksanaan pembudidayaan lebah madu oleh Kelompok Usaha Mekar di Nagari Sungai Buluh yang bekerjasama dengan LPHN Sungai Buluh di Kabupaten Padang Pariaman.Selain itu, tulisan ini juga mengelaborasikan secara ringkas mengenai capaian dan efektivitas pelaksanaan program CSR yang dimaksud bagi perbaikan dan peningkatan perilaku kewirausahaan dan kesejahteraan Masyarakat penerima manfaat.

\section{METODE PELAKSANAAN KEGIATAN PEMBERDAYAAN MASYARAKAT}

\subsection{Waktu Dan Tempat}

Kegiatan pengabdian dilakukan di Hutan Nagari Sungai Buluh, Nagari Sungai Buluh Timur, Kecamatan Batang Anai, Kabupaten Padang Pariaman. Kegiatan demonstrasi pembudidayaan ternak lebah madu ini dilaksanakan oleh CSR PERTAMINA kepada kelompok pembudidaya madu lebah "Bunga Mekal" yang dinaungi oleh LPHN sungai buluh yang mana kegiatan itu berlangsung pada bulan Oktober 2017.

\subsection{Metode Pendekatan}

Pendekatan yang dilakukan dalam mengatasi permasalahan mitra setelah dilakukan identifikasi potensi adalah membuat alternatif rencana kegiatan. Pendekatan yang dilakukan melalui penerapan teknis budidaya praktis yang telah berkembang dimasyarakat melalui media penyuluhan, pelatihan, dan demonstrasi pembuatan produk. Pendekatan tersebut diharapkan dapat meningkatkan pendapatan tambahan bagi mitra dengan mengoptimalkan pemeliharaan ternaknya.

\subsection{Kegiatan Pengabdian}

Kegiatan yang akan dilakukan adalah pelatihan dimulai dari pembuatan stup sampai dapat mengolah hasil madu yang dihasilkan oleh lebah tersebut dan disertai dengan bantuan peralatan yang membantu proses produksi madu.

\subsection{Pelaksanaan Kegiatan Pembudidayaan Lebah}

Kegiatan Pengabdian Masyarakat tentang Pembudidayaan Ternak Lebah Madu ini pada dasarnya dilakukan dalam 2 (dua) tahap, yakni tahap pertama berkenaan dengan Pengenalan dan Pelatihan Teknis Budidaya Lebah dan Pembuatan Demonstrasi Plot Pembudidayaan. Untuk tahap selanjutnya, akan dilakukan beberapa bulan kemudian, setelah lebah berproduksi, dilakukan kegiatan Pelatihan dan Demonstrasi pemanenan lebah dan pengolahan pasca panen. Pada uraian selanjutnya dijelaskan berkenaan dengan kegiatan Pengenalan dan Pelatihan Teknis Budidaya Lebah dan Pembuatan Demonstrasi plot Pembudidayaan Lebah Madu.

\section{a. Pengenalan Budidaya Lebah Madu}

Tujuan dari pelatihan ini adalah para peserta mampu untuk memahami dan menerapkan teknik membudidayakan lebah madu dengan baik dan memahami jenis- jenis lebah madu yang baik dan mempunyai nilai ekonomi yang cukup baik dalam membudidayakannya. 


\section{b. Pelatihan Pembuatan Stup}

Pada tahap ini dilakukan bimbingan teknik dengan mempraktekkan langsung bagaimana pembuatan stup/ kandang lebah madu, penangkapan dan penangkapan ratu lebah, dan menentukan lokasi penggembalaan lebah. Pada tahap ini peserta pelatihan diajarkan bagaimana membuat Stup/ kandang lebah yang baik oleh tim CSR MOR I. Kandang lebah sendiri sebaiknya dari bahan kayu yang bersifat tidak mudah panas, tidak mudah dingin dan tahan air hujan. Ada beberapa jenis kayu yang memiliki sifat tersebut diantaranya kayu sengon, kayu cempaka dan kayu jati. Kandang dibuat dengan satu ruangan yang berfungsi untuk menampung kegiatan lebah ratu bertelur sampai menghasilkan lebah-lebah pekerja yang baru. Ruangan untuk pembiakan lebah ratu ini dinamakan ruang pengeraman. Disamping itu, lebah pekerja menghasilkan madu untuk persediaan makan larva, lebah ratu dan lebah pejantan.
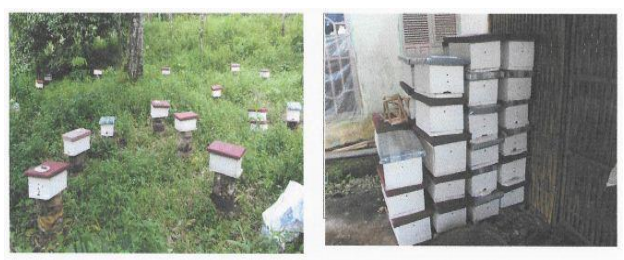

Gambar 1. Stup Koloni Dan Stup Kosong
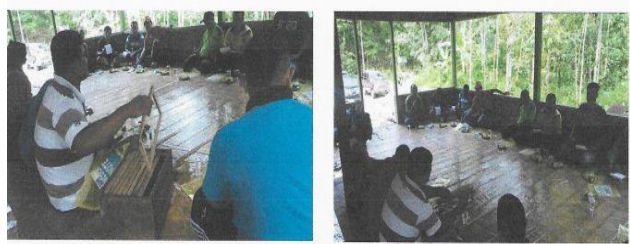

Gambar 2. Penyampaian Materi Mengenai Isi Stup

c. Penangkapan Dan Penangkaran Ratu Lebah Penangkapan dan penangkaran ratu lebah dilakukan langsung oleh peserta pelatihan dalam hal ini kelompok tani yang menjadi mitra binaan dalam rangka pengembangan usahanya.
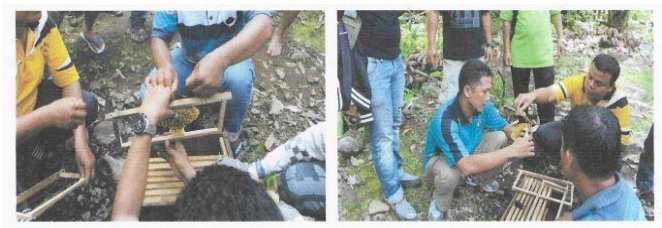

Gambar 3. Pemindahan Sarang Ke Stup Kosong

\section{d. Lokasi Pengembangbiakan Lebah}

Keberadaan dan kelangsungan hidup lebah madu tergantung pada ketersediaan makanan lebah yang berasal dari bunga tanaman, hutan lindung dengan dukungan kondisi geografis tersebut mendukung proses pengembangbiakan lebah madu.

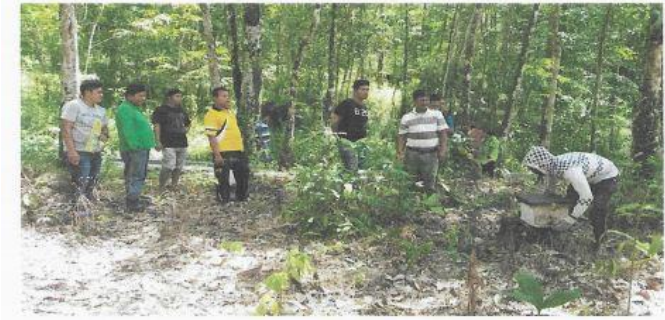

Gambar 4. Lokasi Pengembangbiakan
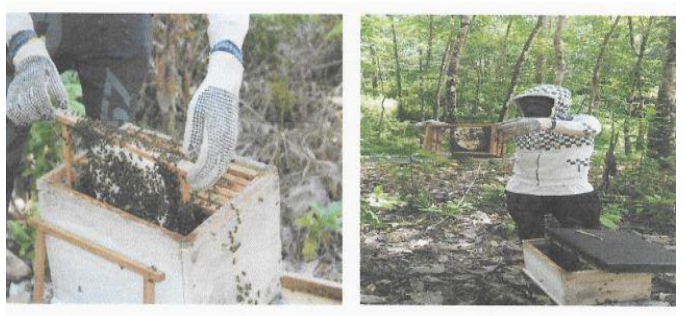

Gambar 5. Stup Yang Sudah Terisi Sarang

e. Proses Pemanenan/ Pengumpulan Madu

Pada akhir tahun 2017 sudah mulai ada yang menghasilkan madu meskipun belum banyak menghasilkan madu namun beberapa stup sudah mulai menampakkan hasilnya.

\section{KESIMPULAN}

Budidaya ternak lebah madu merupakan teknologi budidaya sederhana yang mudah dikuasai dan diterima petani serta berbiaya relatif murah sesuai keterbatasan rumah tangga petani. Produk budidaya ini dapat meningkatkan pendapatan dan kesejahteraan petani. Implementasi program CSR melalui pembudidayaan lebah dan madu hutan oleh kelompok usaha di Nagari Sungai Buluh ini seyogyanya merupakan salah satu program CSR yang dilaksanakan oleh PT. PERTAMINA (Persero) MOR I - DPPU Minangkabau. Rangkaian program CSR lainnya meliputi:

1) Pengembangan Produk Olahan Hasil Laut Kelompok belayan di Nagari Ketaping

2) Pengembangan Kawasan Ekonomi Masyarakat (KEM) di Nagari Tikalak

3) Transplantasi Terumbu Karang di Kabupaten Padang Pariaman

4) Konservasi Penyu di Kota Pariaman

5) Mobilisasi Bidan Desa di Nagari Ketaping, dan

6) Pengembangan Kantin Sehat dan Media Pembelajaran di SMA Negeri 2 Batang Anai.

Kegiatan budidaya lebah dan madu hutan oleh Kelompok Usaha Mekar ini merupakan sumbangsih PT. PERTAMINA (Persero) MOR I - DPPU Minangkabau dalam menggerakkan roda ekonomi masyarakat Nagari Sungai Buluh yang bersinergi dengan upaya melindungi kelestarian lingkungan didalam wilayah yang dikelilingi oleh hutan lindung. pemanenan secara konvensional dan ramah lingkungan. Sebelumnya, oleh penduduk lokal Nagari Sungai Buluh, madu diambil dari pohon-pohon yang berada dalam kawasan taman nasional secara 
konvensional serta memiliki risiko yang tinggi terkait dengan keselamatan nyawa warga yang mengambil madu dari sarang hutan diatas pohon tinggi. Hal ini dilandasi oleh kearifan lokal yang dijunjung tinggi oleh masyarakat setempat dimana mereka memahami bahwa kelestarian hutan yang merupakan habitat madu hutan harus tetap dijaga keberadaannya. Sehingga, melalui aktivitas menjaga ekosistem alami hutan, maka mereka bisa mengambil manfaat lain yang tersedia didalam hutan tersebut.

PT. PERTAMINA (Persero) MOR I - DPPU Minangkabau menyadari sepenuhnya urgensi nilainilai kearifan lokal yang tertanam di masyarakat Nagari Sungai Buluh. Disisi lain, terdapat potensi peningkatan kesejahteraan masyarakat dalam konteks yang lebih luas yang sekaligus melestarikan keanekaragaman hayati di areal hutan lindung Sungai Buluh melalui budidaya lebah madu dan produksi madu hutan yang selanjutnya akan dikelola secara kolektif dalam sebuah lembaga formal yang menjadi lembaga ekonomi Desa/Nagari Sungai Buluh.

Pelaksanaan kegiatan yang bekerjasama dengan Lembaga Pengelola Hutan Nagari (LPHN) Sungai Buluh - Padang Pariaman ini tidak hanya berupa edukasi dan pendampingan budidaya lebah dan produksi madu hutan namun juga mencakup pengelolaan usaha dan pemasaran produk lebah madu secara professional. Hal ini diwujudkan melalui pendirian Kelompok Usaha "Bunga Mekal" sebagai Badan Usaha Milik Desa Sungai Buluh yang sekaligus menjadi branding usaha produksi madu hutan setempat.

DAFTAR PUSTAKA

Abrol, D. P. 2011. Foraging. In: Honeybees of Asia. R. Hepburn and Sarah E. Radolf (Eds). Springer, Berlin Heidelberg. pp. 257-292.

Corlett, R. T. 2011. Honeybees in natural ecosystems. In: Honeybees of Asia. R. Hepburn and Sarah E. Radolf (Eds). Springer, Berlin Heidelberg. pp. 215-225.

Sihombing, D. T. H. 2005. Ilmu Ternak Lebah Madu. Gadjah Mada University Press, Yogyakarta. 